\title{
Negotiating Romania's Destiny During the First World War: An Analysis of Joe Boyle's Diplomatic Strategies
}

\author{
Crina Bud \\ York University \& Technical University Cluj Napoca
}

\begin{abstract}
By investigating formal and particularly informal aspects of Colonel Joe Boyle's diplomatic work during the First World War, this article argues that his actions form an integral part of a parallel, silent, people-to-people, humanitarian diplomacy, and that they stand for his moral imagination. The analysis focuses on Boyle's decisive contribution to Romania's political configuration through his relationship with the Romanian government, the members of the Romanian royal family, and the representatives of European diplomacy; his numerous negotiations with the Bolshevik government leading to the return of the Romanian national archives and its currency, and to the mediation of the Bucharest Peace Treaty in March 1918; and his role in ensuring the availability of food, medicine, and agricultural equipment and in obtaining a loan from the Canadian state for Romania's reconstruction. This article is part of a special collection of papers originally presented at a conference on "The North and the First World War," held May 2016 in Whitehorse, Yukon.
\end{abstract}

The Northern Review 44 (2017): 119-138 
In Charles Cobb's novel The Goliath Stone, the main character of this love and war story is introduced through a dialogue between pilot Armstrong, Queen Maria of Romania, and agent Hill: “Colonel Boyle ma'am? Boyle? Joseph Boyle? Surely not Klondike Boyle? The queen burst out laughing: Is that what they call him. How wonderful! Just like a Jack London character ... Hill grinned: It sounds like the same person. He wears rather a splendid uniform, had it tailored in Saville Row. All his insignia is pure gold from his own mine. Wonderful fellow - absolute dynamo of energy" (Cobb 2004, 56-57).

Joe Whiteside Boyle is a spectacular case of balancing between fiction and reality, between legend and historical records. He acted in real life like a Jack London character, and in Cobb's fictional narrative he represents the warranty of authenticity and credibility for the novel's historical background. The same mixture of verisimilitude and legend stirred the historical interest of Gilles Duguay. After thorough research, he wrote the biography of Joe Boyle-Un Mousquetaire Canadien au service de la reine Marie de Romanie (Duguay 1988). After seventeen years, Duguay was seduced by the enigmatic beauty of the romantic story whose hero was Boyle, and wrote a new book, this time with a fictional aura, L'amour impossible de Marie, reine de Roumanie: récit d'un ancien ambassadeur du Canada en Roumanie (Duguay 2015). In Suit Of Hearts, Daniel Deleanu also retraced Boyle's biography, but organized it on tarot's principles in order to suggest the exceptional nature of a man who seemed predestined to follow uncharted paths. Further, in volume 13 of the graphic novel whose hero is Corto Maltese, Boyle appears like a guide in the northern Canadian and American worlds.

How was this double-sided portrait possible? Boyle's actual destiny is epic, stringing along unusual adventures and experiences and attesting to an historical epoch of transformations. Born in Toronto, Canada in 1867, he spent his childhood in Woodstock, Ontario where his father raised racing horses. At only seventeen years, without any previous training, he went to sea as a crewman on a ship sailing to India. After three years of silence, he returned to New York where he visited his brother and there he met Mildred Josephine Raynor, to whom he would get married within three days.

The periods of luck and bad luck alternated, as if in the life of a roulette player: Boyle won and lost gambling on racing horses and organizing boxing matches for the famous Frank Slavin. Then, in 1897, he decided to 
go to the Yukon where he would spend almost two decades, developing some of the most prosperous local businesses including four dredges, a power plant, timber exploits, and so on.

Yet, not even his diverse and very lucrative businesses, new marriage, older children (four from his first marriage), and younger ones (three from his second marriage with a hotel manicurist Elma Louise), had been enough for this man hungry for life and adventures, who was adopted by the Canadian North. That was the reason he founded and bankrolled a hockey team-Yukon Nuggets - and went with it as far as Ottawa, for instance. When the First World War did not leave any more time for muses (Inter arma silent musae ...) or sports, Boyle used his own money to gather, arm with machine guns, and send to support the war efforts of the Allies, a squad of volunteers. Boyle's life-changing moment came in 1916 and Pierre Berton notes the strange balance: "In the Yukon he made a fortune but squandered it all as a soldier of fortune in eastern Europe at the time of Bolshevik revolution" (Berton 2005, 6).

At the beginning of 1919, Joseph Whiteside Boyle wrote a letter to Canadian Prime Minister Robert Borden requesting the official recognition of his service during the First World War. He also solicited the right to wear the honorific military insignia he was granted in 1916 as an award for the funding of the Yukon Motor Machine Gun Battery. Without any hesitation or ambiguity, he emphasized the fact that this recognition had only a symbolic value to him and, had it been accompanied by any financial gain, he would have donated the money "to Canadian War Charity without publicity" (Rodney 1974, 227).

What did Boyle actually want? More than the formal and, in fact natural, recognition of his accomplishments on the southeastern European battlefield, he wanted to give coherence to his own destiny, torn between his legend as a Yukon man, or as King of the Klondike, and his still-fresh fame as an ingenious and brave military man.

Thus, he was not seeking material comfort, but the right to be himself: a right that was always contested because his presence shocked, fascinated, and irritated at the same time. His refusal to obey any hierarchy, as well as to accept labels and/or any kind of regimentation, offended many political and military personalities.

On the outside, he had earned the right to wear the Canadian officer uniform, although his version was customized: the collar badges, designed for him and his squad by the Jacoby Brothers of Vancouver, featured pure Klondike gold, while under the royal crown appeared the inscription, "Boyle's Yukon." 
The medals awarded to him by several European countries for his heroic deeds were added, one by one, to this custom-made outfit: Distinguished Service Order (England); Croix de Guerre (France); Star of Romania (Grand Cross); Crown of Romania; Order of Regina Marie (Romania); and Order of St. Vladimir, Order of St. Anne, and Order of St. Stanislaus (Russia). His cosmopolitan appearance stirred the anger of the Canadian military staff in 1919. General Turner imperatively asked Boyle to stop wearing his uniform. Canadian officers soon had to give up on their resentment, as King George V asked Boyle to wear his well-deserved uniform and military medals, particularly during his frequent visits to Buckingham Palace where he accompanied Prince Nicolae of Romania.

Even before the medals started piling up on his chest, his mere presence in military uniform electrified the crowd but hurt the pride of representatives of military, diplomatic, and political authorities. Martin $\mathrm{H}$. Donohoe, a well-known war correspondent, reported on the threat, which field marshal August von Mackensen, the commander of the German occupation army in Bucharest, made to the Romanian minister of defence: "Tell him to take off that uniform or I shall have him shot"(Rodney 1974, 192). From this outburst, we can infer the German officer's extraordinary vanity, but his angst was nevertheless justified. One of the conditions imposed by the Germans on the Romanian people, after the German occupation of the southern part of the country, was for all Allied soldiers to withdraw from the territory under German control. Not only did Boyle reply sarcastically to Mackensen, ${ }^{1}$ but his slights were numerous. He was the only foreign officer who attended a service held for the Romanian soldiers fallen in battle, organized by Queen Marie of Romania, despite the Germans having banned any kind of commemoration. Similarly, he was the only Allied officer who remained with the Queen on the train station platform when the French military mission, the British, and the American solders had to leave the country (12 March 1918). He was actually the one who facilitated their journey by rail through Russia, at a time when any other route would have meant risking capture by the Germans. General Henri Berthelot, the French commander, noted in his diary his appreciation for and trust in the Canadian for the essential help he provided, despite making ridiculing remarks at their first meetings: "Le colonel Boyle m'a dit être chargé par les Bolshevicks d'Odessa d'offrir la paix aux Roumains! En quelle qualité! Il est d'une prolixité odieuse et je ne puis m'en débarasser" (Torrey 1987, 160)-translated "Colonel Boyle told me that the Bolsheviks of Odessa had commissioned him to bring peace to the 
Romanians! In what capacity? He is one of those despicable, long-winded types, and I can't get rid of him!“

What I am trying to underline through this attempt at portraying him is that, surprisingly, for him the uniform was not a symbol of subordination but rather of his complete autonomy in making decisions and of his authority during the most dangerous actions. There are many testimonies of the surprise and frustration experienced by numerous diplomats, politicians, and officers from both sides. The frantic scene of the First World War was defined by this kind of unusual, hard to classify, ambiguous personality. The Germans camped in Bucharest would have not only wanted Boyle expelled at any cost, but also Robert de Flers, the press attaché of the French Embassy (who, among others, discovered that anthrax and glanders bombs were being developed at the German embassy in Bucharest), or Emile Henno, Boyle's temporary partner while in Bessarabia, who was another unusual, non-conformist, and nontraditional person and who proclaimed himself the vice consul of Kiev, the main organizer of an anti-Soviet conference in Jassy in 1918.

In comparison to de Flers and Henno, Boyle relied upon the experience and wealth earned in the Yukon, as well as on what contemporary analyses of semi-diplomatic negotiations for conflict resolution identify as "the moral imagination," as described by J. P. Lederach in his book The Moral Imagination: The Art and Soul of Building Peace. Boyle presents all of the four qualities that define the moral imagination according to Lederach: "the capacity to imagine ourselves in $a$ web of relationships that includes our enemies, the ability to sustain a paradoxical curiosity ..., the fundamental belief in a pursuit of the creative act and the acceptance of the inherent risk of stepping into the mystery of the unknown that lies beyond the far too familiar landscape of violence" (Lederach 2005, 5). However, to what "type" of diplomacy his actions could belong and be assessed is very hard to establish. In any case, terms such as "track-two," "multi-track," or "track and a half" (cf. Jones 2015), are relatively recent concepts, and the criteria of systematization and prioritization prove irrelevant for a man who did not operate in half-measures. Still, any of the terms currently being defined or redefined in today's international relations lexicon to describe semi- or unofficial diplomatic negotiations could serve to highlight the many nuances of Boyle's activities in Russia, and particularly in Romania. The instances I briefly present below lend themselves well to terms such as parallel diplomacy, silent diplomacy, people-to-people diplomacy, or even humanitarian diplomacy. Judged in the context of "the diplomacy of chaos," in which "acrimonious, contradictory, secretive, and self- 
interested interplay among the Allies was the dominant factor" (Moffat $2015,68)$, Boyle's actions, often justified by principles, seem to be part of a rather coherent personal project. Boyle was one of the important actors in a clandestine war, a freebooter, but one who took risks and major responsibilities when official diplomats chose to remain in the shadows. ${ }^{2}$

The military and diplomatic services tried several times to subordinate and tame him through threats or promises. They were unsuccessful every time. One of the reasons for this reluctance to subordination can be found in Boyle's report to chief of the general staff in London, January 1918: "the impossibility of maintaining my freedom of action if I had to refer everything [to the British and American Transport Missions]."

It is known that Boyle was part of a network of around 450-500 agents of the Allied Intelligence Service, but even there he was an exception. He refused to be assigned a code name such as "1K8," the way George Alexander Hill, his partner in missions and adventures, identified himself.

The fact that he only spoke English did not prevent him from leading some of the most intense relationships and mediations in Russia and Romania. Boyle possessed exceptional qualities that wise coordinators knew how to nurture and use. One such coordinator was the admiral Reginald Blinker Hall, who knew to put the members of the diplomatic annex "Room 40" at England's disposal. The annex was judged by its contemporaries in these terms: "It is true that, if for the better prosecution of the war you collect such [an] imposing array of men of intellect, it is extremely difficult to groom and guide them as you do with men of a lesser calibre and more normal temperament" (Andrew 1987, 15). The few who truly discerned Boyle's intelligence and inner (including moral) force discreetly supported him.

Joe Boyle owes the beginning of his military career and adventures to his impressive "web of relationships," and that is the essential foundation for the manifestation of the moral imagination. He had collaborated prior to 1917 with the "Honorary Chairman" of the American Committee of Engineers, C.W. Purington, and he took advantage of this connection in the new context. His first mission in Europe, as a representative of the American Company of Engineers, was to help organize the railroad transportation system in the south of Russia during a difficult time when shipping food and medicine was almost impossible, and both the soldiers and the civilians seemed condemned to starvation and devastating epidemics.

The competence of American engineers had been already proven on the French front in the first two months after the United States entered the 
war, and no fewer than nine regiments worked on building bridges, road, and railroads. Thus, the Russians were open to and trusting of Boyle's plans. The immediate results of the repairs and of his solutions, that exploited to the highest degree the geographical setting and combined rail and water transport, shortly saw him appointed temporary counsellor to the Russian government and then chairman of the All-Russian Food Board. From this position he would ensure the flow of relief supplies to Romania.

Why did those resources have a major impact in Romania? In November 1917 the Romanian government and the royal family had been taking refuge for over a year in Jassy (the largest city in northeastern Romania), while Bucharest, the capital city, and the entire southern province of Romania, were under German occupation. The armistice signed with the Central Powers after the Soviet Russians left the war (the Treaty of Brest-Litovsk, signed on 3 March 1918), and the subsequent peace treaty between Romania and the Central Powers (signed on 7 May 1918), required Romania to cede territories, as well as to give Germany the monopoly on wheat and wood, and especially - for not more than ninety years - the right to exploit oil.

In the attempt to limit the enemy's benefits, the Allies, forced to withdraw, destroyed 1,677 oil wells, twenty-six refineries, and tanks containing 827,000 litres of crude oil. Isolated from its Western allies, surrounded by territories occupied by the Central Powers, Romaniaor the Triangle of Death, as it was sometimes known-was completely dependent on Russia for its food, ammunition, and medicine supply. The winter of 1916-1917 was terrible, with constant temperatures below minus forty. Life in the surrogate capital of Romania was bleak, with hundreds of people dying of cold or starvation. In addition, a "sanitary catastrophe" (Grandhomme 2010, 116) showed itself in the form of several contagious diseases, such as typhus, cholera, meningitis, and the bubonic plague. Boyle's depiction of the collapse of the relief system shows up the atmosphere of confusion and despair: "The position then, was, that Russia had about 1,100,000 men in Romania, and had not shifted a pound of flour for some weeks, whereas, this army was eating a bread ration of 2lbs/per day per head, and the Romanian wheat was disappearing very fast, and to such an extent that Romanians figured they would be completely out by January" (Boyle 1927, 226). Boyle's technical solutions in this striking context had a saving effect: "I arranged with the South Western group at Odessa to get some light draft boats for Lake Jalpooh, and made out a system which was subsequently carried out, and which for several 
months and, in fact, as late as they could operate delivered about 500 tons per day to Romania" (Boyle 1927, 226). Thus, he became indispensable to the Russians, who put him "in charge of the procuring of the fulfillment of the protocol between Russia and Romania for both food and clothing." According to the agreement signed on 25 April 1917, the Russian and Romanian armies were considered and treated as one and the same, even by the International Commission of Relief indirectly represented by Boyle. The results of his actions were immediate: "The work turned out very fortunately and they had over two thirds of the goods promised them by Russia delivered withen two months, although prior to this time they had never received one garment" (Boyle 1927, 227).

In order to achieve this difficult mission, he made use of an authority he did not really have (which he frankly admitted), and even requested, at some point, to be granted the rank of an army general because "a general here receives attention and homage from almost everybody whereas they look with a certain amount of familiarity ... upon a colonel and raise questions they otherwise would not think of"' (Sauerwein 2003, 66).

So, he needed to imagine a military authority in order to make possible the development of creative acts. After the Bolsheviks' rise to power, Boyle's diplomatic creativity was in high demand as his objectives multiplied. It went without saying that he represented British interests in Moscow, and it was clear that the Russians trusted him in the wake of his concrete actions. Under these circumstances, his status as a double agent could not be called into question. However, as Gilles Duguay-a former Canadian ambassador to Romania-emphasizes, Boyle's commencement of negotiations with the Bolsheviks on behalf of the Romanian people tripled his diplomatic avenues. Following his actions, requested by the French general Berthelot to create confusion in Northern Russia by jamming railways at the border with locomotives, he can be considered an "agent of four countries" (Duguay 1999). Throughout this time, he would consistently serve the Entente interests and with much conviction would strive to warn of the threat posed by the Bolsheviks. Not only did principle and clairvoyance motivate him to serve Romania, but also his heart after his meeting with Queen Marie. From the start, he perfectly understood Romania's tragedy: a country run by a king with German origins, which chose to enter the war on the side of the Entente and, while desperately trying to keep its promises, discovered itself impoverished, torn apart, and crushed between the German and the Soviet interests.

Fuelled by a paradoxical curiosity, his creative strategies would soon bear fruit. Ensuring the availability of food, medicine, and agricultural 
equipment was one of his meticulously-implemented and ingenuous endeavours undertaken both during and after the war. In late fall of 1917, Boyle unsettled British diplomats with his plan to supply Romania with the basic necessities through indirect means. The British Ambassador to Jassy reported: "I heard that Boyle has submitted a scheme to the Romanian Government for obtaining goods from abroad, for arranging finance of same with Governments concerned, and for appointment of Committee of American Engineers in London to direct purchasing and forwarding" (Rodney 1974, 129). Navigating his network carefully and cleverly, and taking diplomatic steps as if walking a tightrope, he did his best to exploit the goods left behind by the Russian army after the Treaty of Brest-Litovsk (the goods were only left in Romanian custody, not possession). Some of these goods were meant to sustain the White Russian army, but the vast majority was to be kept and administered in Romania. Never did Queen Marie's diary reach such a height of enthusiasm as during the weeks when Boyle explained, and later applied, his plan to form a private medical organization, the Order of Queen Marie. She exulted as she rarely did: "he was prepared to instruct me in many subjects ... he wakens me from numbness and prepares me for new efforts" (Maria 2015, 251); "I am planning big things with Boyle" (Maria 2015, 281); "he is trying to convince me to take more ample action to help starving mothers. He says he can find the money" (Maria 2015, 281); "It is wonderful to have a man like Boyle around, it is wonderful not to doubt, not to be afraid, but just fully rely with all your trust on someone" (Maria 2015, 281); "I have never seen such a meeting of caution and altruism" (Maria 2015, 299). In all of these affirmations we can hear the voice inflections of a woman in love, but also of a pragmatic queen who foresaw the political impact of the planned actions.

Exhausted by overwork and stress, Boyle had a stroke in June 1918. Queen Maria hosted him in a royal chalet in Bicaz and assisted him with his recovery. The Bicaz chalet where Boyle recovered from his stroke became a sort of situation room for negotiations and strategic analysis.

Here, he met members of his network of informants and Bessarabian officers. In the same location he discussed the medical foundation in a polemical or constructive manner with General Baliff (administrator to the Crown and regal aide); Colonel Elin (Russian official in charge of Red Cross assets in Romania); the Queen's doctor, Mamulea; as well as various businessmen and lawyers. The Queen found herself in the unusual position of translator: "I translate for him all the time, in every direction" (Maria 2015, 281). In addition, she pleaded in support of their common 
cause with the Romanian Prime Minister, Alexandru Marghiloman, who officially approved their purchase and sale of Red Cross goods. The enterprise would not achieve the grandeur that Boyle envisioned, but at least a third of the supplies were won for Romania in the end.

With the same vigour, he participated in the foundation of collective agricultural farms in Bessarabia so that the wool, sugar, and wheat did not go to Germany. He provided transportation for supplies to the most remote areas, using trucks, automobiles, military vehicles, and/or his two personal trucks. At the end of the war, he made plans to take over as many German Red Cross supplies, still on Romanian territory, as possible. At the same time, Boyle kept his eye on the important hospital in Coțofenești, where he visited the Queen several times and, even more significantly, performed acts of charity in the surrounding villages: "he bought a cow for one village so the children would have milk, in another village he bought an abandoned house, rebuilt it, and gave it to three refugee families in the name of Princess Ileana. He supervised repairs, ferreted out supplies, and gave away untold amounts of money" (Pakula 1985, 245). Boyle involved Princess Ileana (the queen's youngest daughter) in these humanitarian efforts, and always claimed to make his donations in the name of Queen Marie, "as if they had come from me ... as if at my behest," she noted, obviously touched (Maria 2015, 301).

In reality, all these discreet charitable actions were the foundation of a truly altruistic political program aimed not only at immediately and effectively improving the Romanian peasants' quality of life after a devastating war, but also at giving Queen Marie, the active supporter of this program, an undeniable political advantage. So, he converted his moral capital to a political one in favour of the queen. In a letter from November 1918 Boyle presented his plans to the Queen, proving that his principles were firm, unchanged by the war's constraints or peace's euphoria and confusion. The letter below shows that he was always a step ahead of everyone else, with a grasp of economic mechanisms that would become apparent only much later:

My idea is that I can get in touch with Mr. Hoover and have him purchase for Romania what she needs immediately through either the Commission for Relief in Belgium or through channels through which foodstuffs are purchased for the Allies - in this way saving you both the middleman's profit and any expense either by way of salaries or commissions as there would be no charge. 
My idea further is that now is the time for your majesty to spend the two and a half million dollars given you by the American Red Cross, use your own ships and get condensed milk and rice by the quickest possible methods; this will enable you to render a service to your newly acquired territory (Bessarabia) and to the occupied territory that will never be forgotten - this service will be rendered at a time when all of the country surrounding you is in the most terrible distress and will be a big factor in settling in the peasants' minds the differences between intelligent organized efforts on the one side and mob rule on the other.

(Rodney 1974, 216)

Thus, his status had never been that of a regular military man, businessman, supplier, and/or engineer with technical solutions for transportation in difficult situations, and not even that of a secret agent. For these five activities, five distinct persons would have been needed! But for Boyle, those were only five ways to apply his vision borne out of his moral imagination, to anticipate possible future developments. Even more than that, he also acted as political counsellor, earning his reputation as the "grey eminence" of the royal house, a title disparaged by opponents through comparisons to Rasputin or Machiavelli.

The most important thing that Boyle immediately understood was that Romania had to preserve its stability and independence and stay on the Entente's side in order to regain the territories from Transylvania, Bessarabia, and Dobrodgea, but he also understood the actions behind the scenes of the countries that craved to gain control over different territories inhabited by Romanians.

Romania's independence was indeed threatened. Moving the government to Crimea, in Poltava or Herson, was seriously considered, and the Russians were preparing, with open enthusiasm, a palace for the royal family, while the Romanian army was supposed to be displaced to Russia and from there transported by the British navy to the Western Front. If this strange migration had taken place, Romania would have found itself in the aberrant position of a country without a territory, without leadership, and without an army, and it would have been impossible for it to make any demands at the end of the war. The major rationale for the country's entrance into the war, after two years of neutrality, was exactly to recover those territories that were predominantly Romanian. The turbulence was so high that even a so-called "Party of the Evacuation" was founded. The King, at the Queen's insistence, refused to leave the territory of his country 
no matter how small and impoverished it had become, and, in addition, he refused to sign a peace treaty with Germany; when his government signed, he found all kinds of subterfuges to delay its ratification.

Thus, Germany's hostility became manifest through several attempts to eliminate the royal couple, either through assassination, deportation, replacement, and/or through a secret collaboration with the Bolsheviks who were trying to instigate the fall of the monarchy in Romania. The proGerman Romanian government, headed by Alexandru Marghiloman and installed in March 1918, secretly planned the disposal of the royal family or even of the dynasty, and to this end the truly powerful personages needed to be sent away - the former Prime Minister Brătianu and particularly the Queen. Marghiloman's diary indicates as much: Brătianu had to leave the country and, sarcastically, he suggested that the Queen would visit her mother because "she will be gripped by an unexpected longing" (Marghiloman 1993, 411).

Through his involvement in Romanian politics, Boyle contributed to Romania's political stability by ensuring the coherence guaranteed by the monarchy's survival. Unfortunately, Romanian monarchy was threatened not only by war's conflicts and unpredictable developments, but also by inner struggles. Prince Carol, the heir to the throne, had a turbulent youth, far from the rigour and dignity required for a future king. The future of the monarchy was truly jeopardized when Prince Carol ran away and secretly married Zizi Lambrino, a woman considered inappropriate by both the royal family and Romanian politicians. In fact, he also abandoned his military duties, which could have brought him in front of the martial court. Catastrophe seemed imminent, but the man of perfect arguments and appropriate attitudes, Uncle Joe, as all the royal children knew him, chimed in. After hours and hours of discussions, Boyle, the fixer, convinced Prince Carol to break up with the woman for whom he had a devouring passion. Then the same Boyle established the details of a seven month trip for Carol so that the young man would forget and grow up. At the end of this journey around the world (from Istanbul to Egypt, India, China, Japan, and the United States), Prince Carol made the acquaintance of Boyle's daughter, Flora, in New York.

From the letters written by Carol to Zizi, his new and troublesome wife, during his negotiations with Boyle, we can see the prince's trust and respect for this strange mediator. Boyle was the only one who had moral authority over Carol, as well as the ability to offer him moral comfort. His parents, the King and Queen, stood aside, waiting for Boyle to ensure the future of their dynasty and protect the rebellious young prince's destiny. 
From the first moment, it was clear to Carol that trickery had no place in their discussions: "Voilà colonel Boyle qui s'annonce. J'ai bien compris qu'il était venu pour parler des choses graves ... il tâche de me montrer la faute que j'ai faite et que la seule façon de la réparer, c'était en te lâchant." (Translation "Here was Colonel Boyle ... I saw that he had come to talk about serious matters. He tries to point out the mistake I made and that the only way to fix it would be to release you." (Carol 2003, 65).The Canadian facilitated the exchange of letters between the two young people as well as communication with the royal palace. In his meetings with Zizi Lambrino, he managed not only to avoid betraying Carol's trust, who wished to convince her of the persistence of his sentiments, but also the Queen's confidence, on whose behalf he urgently needed to determine their divorce. The entire episode had a happy ending because, after the expected divorce, Carol eventually married Princess Helen of Greece and ensured the succession to the throne.

All of the other royal children enjoyed Uncle Joe's presence, gifts, humour, and endless stories during their various travels, private meals, and Christmas celebrations, to which he was always invited. After Boyle used his wisdom and discretion to alleviate the scandal triggered by Carol, the Queen sought his support with her other children as well. Subsequently, he accompanied Prince Nicolae on his trip to England and Eton College, and took care of Princess Ileana when she had to stay without her mother at Buckingham Palace due to illness.

Boyle's contribution to the stability of the Romanian dynasty, and even the state, is not limited to designing specific-creative-strategies or handling internal conflicts. Indeed, Boyle became personally involved in settling some conflicts that could have disintegrated the small country. I will review only some of his efficient interventions in maintaining the power balance in Southeast Europe. All these actions are an illustration of the fourth condition of the moral imagination: the willingness to take risks.

The first intervention was related to the decision at the end of 1916 to send the Romanian National Treasury to Russia for safekeeping, followed, in July 1917, by the even more drastic decision to move the Romanian National Bank there. Thus, in only two trips, Romanian documents, manuscripts, art, the jewels of the Romanian royalty, the archives, the paper currency and the printing press for it, and over 120 tons of gold, were sent to the Kremlin on dozens of freight cars. Moscow was considered only a temporary hideaway, as the Romanian government hoped to relocate the treasury to the United States. Boyle offered the practical and perfectly feasible solution of transporting it through Siberia. Negotiations for such a move were started, but the plan was cancelled because the Allies did 
not offer any guarantees. After the Bolsheviks' rise to power in November 1917, Romania did not recognize the new Russian government and even started to disarm and evacuate the Bolshevik soldiers who stopped taking orders from the Imperial Army officers, creating chaos in Romanian communities and on Romanian territory. Under these circumstances, the new Soviet government confiscated the Romanian treasury. Leon Trotsky, then the commissioner for external affairs, explained that those treasures belonged to the people and had to be protected against the capitalists.

To protect the national treasure, the Romanian government sent twenty soldiers to Moscow, "in civilian dress, armed with revolvers ... They could not fulfil their mission ... Anyone wishing to gain access [to the Kremlin] needed a special permit issued by the Bolshevik authorities" (Romascanu 2000, 61). The Romanians searched desperately for solutions to recover at least the foreign affairs archive, as well as the Romanian paper currency and the means to print it, in order to avoid a diplomatic and financial collapse. Constantin Diamandi, the Romanian Ambassador to Russia, appealed to Boyle - the man who, naturally, held such a permit - for help. In Go Spy the Land, G.A. Hill describes the challenges involved in transporting around twenty tons of materials and twenty Romanian soldiers stateside at the same time, a feat worthy of a Hollywood adaptation. Boyle, meanwhile, chose to keep the dangers under wraps and recorded only the positive outcome. All the historians who have investigated this episode, including William Rodney, agree that the twenty-five day mission, in extremely dangerous conditions, could not have been accomplished without Boyle: "Because of his unique position as the unofficial 'tsar' of the railway system in southwest Russia, because of his work in Romanian relief operations, and because of his extraordinary effort in clearing away the blockage around Moscow, he enjoyed the confidence and respect of both the Bolsheviks and the Romanians" (Rodney 1974, 150). Hence, at the end of this extraordinary trip, on Christmas Day 1917, Boyle gave Romania the first of many gifts.

A second gift followed shortly thereafter. Only a month later, Romania's situation became even more dire. Bessarabia declared its independence on 24 January 1918, taking advantage of the Declaration of the Rights of the Peoples of Russia signed by Vladimir Lenin and Joseph Stalin on 15 November 1917 during the days of enthusiasm and confusion after the Bolshevik Revolution. Unfortunately, this territory, which was claimed at the same time by Russia, Ukraine, and Romania, was unable to secure civil order in the conditions of anarchy and required the support of the Romanian army (through general Cherbachev, the former 
commander of the Russian imperial army). The Romanian army occupied Bessarabia and Lenin "reacted angrily ... breaking off diplomatic relations, confiscating the Romanian treasury held in Moscow, and imprisoning ... the Romanian minister. In Odessa, the Rumcherod, a Bolshevik militaryrevolutionary committee ... initiated a reign of terror against the large number of Romanian citizens that had taken up refugee there" (Torrey 2011, 275). In February Boyle hastily returned to Odessa, trying to negotiate peace between the Romanians and the Bolshevik Russians. It seems that the Russians themselves, concerned about the imminent attacks of the Central Power armies, wanted to settle this conflict and asked Boyle to intervene through one of the commanders of the Russian navy (M. Speiro). Boyle's first decision was to call a conference of the Allied officers and diplomats at that time in Odessa and to ask them to start talks with the Supreme Council for a possible peaceful solution. For five days he negotiated with Russian leader Rackovsky, relying on information he was sure of: "both Rackovsky and Mourafiev [an ex-tsarist officer who joined the Red Army] were certainly German agents" the Canadian claimed in his later report (Boyle 1927). He also counted on his intuition, persuasion, and physical endurance. Indeed, on the fifth day, at 6 a.m., Rackovsky gave in, exhausted.

The protocol signed in Odessa on 23 February would be ratified by the Romanian government, and Boyle subsequently returned to Odessa on a plane provided by General Berthelot, who fully understood the importance of this treaty, although its real significance would become clear only during the Paris Peace Conference when Bessarabia returned to Romania, also thanks to this wise diplomatic initiative. Boyle's irritation when the Romanians did not immediately respect the terms of the peace, jeopardizing the treaty, proved that he already anticipated this final objective. It was not the first time when his political intelligence, based on decisiveness and prompt action, was aggravated by the procrastination specific to Eastern Europe. When her friend intransigently criticized the Romanians for "making themselves disliked instead of loved" in Bessarabia, Queen Marie sorrowfully noted in her diary: "Sometimes East and West cannot meet!"

Proactive, always anticipating his collaborators' next move, Boyle returned not only with the signed peace treaty, but also with an agreement from the Romanian side that offered to exchange the four hundred Russian prisoners for the seventy Romanian diplomats incarcerated at the Turma prison. The mission to save the group consisting of the vice-president of the Romanian senate, generals, high naval officials, senators, members of 
the parliament, some wealthy men, and others, was a real achievement. In her memoirs, Romania in Light $\mathcal{E}$ Shadow, Ethel Greening Pantazzi, the Canadian-born wife of a Romanian diplomat, describes the strong will and even the physical endurance Boyle proved during the negotiations and the challenges that followed. But here, I am referring to the tour de force of the negotiator, of the subtle connoisseur of human psychology, and the natural strategist.

The trip from Odessa to Galați, a city in modern-day southeastern Romania, started with an agreement with the same Bolshevik leader Rackovsky (who eventually broke his promise and ran away, apparently with the prisoners' money and valuables), then with members of the Death Battalion and the prison guards. The trip continued with negotiations with representatives of the Black Sea Fleet at Sevastopol and the Romanian government's request to German Field Marshal Mackensen to make the exchange in a place under the control of the Central Powers. At the end, when everything seemed settled, the Austrians, who were the actual occupiers of Galați, did not want to recognize the document signed by Mackensen. Although he only spoke English, Boyle always made himself understood, adapting to personalities and circumstances. The significance of this action is also underlined by the French ambassador to Romania, the Count de Saint-Aulaire, in his memoirs: "[the prisoners] only escaped torture and death thanks to the Austro-Hungarian occupation of central Russia and the intervention of Canadian Colonel Boyle, to whom I delegated their care, who, with admirable energy, revolver in one hand and pounds sterling in the other, snatched them out of their executioners' gaping maws" (Saint-Aulaire 2002, 196) The "adventure" ended in a triumph, the trade of prisoners took place, the crowd welcomed them with flowers and cheers, the King awarded Boyle the Star of Romania, a street in Galați received the Canadian colonel's name. The people he saved wanted to repay his courage through a commemorative medal, for which they commissioned talented French artist André Lavrillier. The front of the medal shows the colonel's likeness, and the back displays "a ship with full sails, the ship that rescued our refugees" (Buletinul 1919, 35).

Prime Minister Marghiloman, the very same that would have liked to banish the Queen from the country for a period, describes the hero in the making. He balances between two labels for Boyle: a watchdog or a guardian angel. On the one hand "he appointed himself the watchdog of our interests in Russia but he would particularly fight so that our ships would not fall to the Germans" (Marghiloman 1993, 455). On the other 
hand, he is a "very interesting colonel ..., the guardian angel of Romanians held for ransom by the Bolsheviks" (Marghiloman 1993, 423).

Unfortunately, some months later, Boyle's involvement in the "Carol affair" was subsequently denounced in Romanian socialist newspapers and he became the favourite target of public scandal after the war, the purpose of which was the slander and weakening of the Romanian monarchy. The King actually acknowledged in an official letter to W.F.A. Rattigan, first secretary HM Legation Bucharest and Jassy, that Boyle "is being used by the extreme socialists as a stalking horse for attacks upon himself" (Rodney 1974, 257). These tensions plus his involvement in the oil business would bring Boyle the biggest deception and sadness of his life: to stop the Socialists' and the Bratianu government's gossip and machinations, the Queen asked Boyle to leave Romania!

After the war, Boyle found himself harassed by the distrust and vain revenge of some British and Canadian officials, on one hand, and by the Romanian politicians who were irritated by his position as the unofficial counsellor of the royal family, on the other hand. Of course, his unofficial diplomatic status did not allow him to participate directly in the peace negotiations in Paris, but this did not stop him from finding the right tools to draw the participants' opinions in Romania's favour. A consistent exchange of messages took place between Queen Marie and Boyle. In Paris, where her presence dazzled everybody, she met numerous influential persons following his introductions. All those personalities of world politics at the time, including "the not particularly congenial" Herbert Hoover (Mandache 2004, 36), the future American president, had a positive reaction to the recommendation-and then to the charm of the queen - and this attested to the high quality of Boyle's network and the respect he had earned. The Queen's diary recorded a similar type of support during her visit to England after Paris, when Boyle, coming to Buckingham almost daily, brought with him "anyone who (he) considered it useful for me to meet" (Mandache 2004, 51).

He personally took over the difficult task of convincing Robert Borden, the Canadian prime minister, to offer a substantial financial support to Romania. Borden gave in to his insistence, promised an aid of $\$ 5$ million. The media, however, released the news that Canada was going to offer $\$ 25$ million to Romania. Exasperated, Borden suspected Boyle of actually providing this number to the media in order to force his hand to allot a bigger amount of money than he intended. No one knows for sure if it was an instance of (a)moral imagination or just a correct prediction. But it is well known that Romania eventually received \$25 million as financial 
aid, and Boyle became the first official Canadian diplomat in Romania to administer this loan.

In an article published after Boyle's death, Queen Marie underlines the rare combination of softness and gentleness he showed in personal relationships and his intransigence, sometimes harsh, in his social and professional relationships. "He had always kept faith and could not conceive that anyone could doubt his word. ... With us he became soft and gentle, he had a great simplicity about him, sometimes almost the simplicity of a child. ... He sometimes used such curious expressions, quaint forms of speech, his way of speaking was so irresistibly humorous, and every day there was still some exciting event to discover, some thrilling episode to listen to. But this I must say, he could only take a leading attitude, he had to dominate; ... he never could play second fiddle, he had to have things his own way" (Queen Marie 1926, 1). She summarized his strong and paradoxically ingenuous personality through Robert Service's words, which she chose for his funeral stone: "a man with the heart of a Viking and the simple faith of a child." This unique mixture of kindness and harshness nurtured his moral imagination

After the Treaty of Trianon, what only a few years before seemed impossible happened: Romania's territory tripled in size. A utopian ideal became reality, uniting together in one nation-state the Romanians from Moldova, Wallachia, Banat, Bessarabia, Dobrodgea, and Transylvania. On 15 October 1922, in Alba Iulia, Ferdinand was crowned king of all Romanians. Queen Marie attended the ceremony on her horse, Austral, which her "faithful, good old Joe" had given to her hoping for this very moment of grace. I do not know if the horse's name (meaning South) was chosen by Boyle, but I find it very significant because the man from the North, through his moral imagination, contributed to the reconfiguration of the South of Europe and fulfilled his exceptional destiny.

\section{Author}

Crina Bud is lecturer of Romanian language and history at Glendon College, York University, Toronto, Ontario, and at the University \& Technical University Cluj Napoca, Northern University Centre, Baia Mare, Romania. 


\section{Notes}

1. "Tell him," answered Boyle, "that no German living will compel me to take off my uniform. I carry a single-action Colt, and I am a man of my word: I promise to drill holes in the first German, be he general or private, who lays violent hands on me" (Rodney 1974, 192).

2. In his book, Dances in Deep Shadows: The Clandestine War in Russia, 19171920, Michael Occleshow situated Boyle among prominent figures of British intelligence-Sydney Reilly, Sir Paul Dukes, Francis Cromie, Reginald Teague-Jones. By quoting C. Ballard (the British Military Attache to Romania), the author underlines the complete transfer of responsibility to Boyle: "I asked him to embarrass the enemy in any way he could without limit of any kind ... I discussed with him all his plans and told him that he must be the judge," 105-106.

\section{References}

Andrew, Cristopher. 1987. "Secret Intelligence and British Foreign Policy 1900-1939." In Intelligence and International Relations 1900-1945, edited by Christopher Andrew \& Jeremy Noakes, 9-28. Exeter: University of Exeter Press.

Berton, Pierre. 2005. Prisoners of the North. Anchor Canada.

Boyle, W.J.A. 1926-1927. "Canadian Officer's Adventures among the Bolsheviks.” Canadian Defence Quaterly, Vol IV, Oct. 1926 to July 1927: 225-234.

Buletinul societății numismatice române. 1919. Anul XIV, nr. 29-30, Jan-Jun 1919.

Carol al II-lea. 2003. Intre datorie și pasiune, Insemnări zilnice, Vol I (1904-1939). Bucharest: Curtea Veche.

Cobb, Charles. 2004. The Goliath Stone. Trafford Publishing.

Deleanu, Daniel. 2012. Suit Of Hearts. LogoStar Press.

Duguay, Gilles. 2015. L'amour impossible de Marie, reine de Roumanie: récit d'un ancien ambassadeur du Canada en Roumanie. Québec: Text et Contextes.

Duguay, Gilles. 1999. Regina Maria și Joe Boyle, o prietenie de suflet. Bucharest: Du Style.

Duguay, Gilles. 1988. Joe Boyle - Un Mousquetaire Canadien au service de la reine Marie de Romanie. Bucharest: All.

Grandhomme, Jean Noel 2010. La Roumanie de la Triplice à l'Entente 1914-1919. Paris: Soteca.

Jones, Peter. 2015. Track Two Diplomacy in Theory and Practice. Redwood City, CA: Stanford University Press.

Lederach, John Paul. 2005. The Moral Imagination: The Art and Soul of Building Peace Oxford, MA: Oxford University Press.

Mandache, Diana (ed.). 2004. Later Chapters of My Life: The Lost Memoir of Queen Marie of Romania. Stroud, UK: Sutton Publishing. 
Marghiloman, Alexandru. 1993. Note politice. Vol II Editura, Machiavelli, Bucharest. Maria, Regina României. 2015. Jurnal de război 1917-1918. Humanitas, Bucharest.

Moffat, Ian C.D. 2015. The Allied Intervention in Russia, 1918-1920: The Diplomacy of Chaos. London, UK: Palgrave Macmillan.

Occleshow, Michael. 2006. Dances in Deep Shadows: The Clandestine War in Russia, 1917-1920. New York: Carol \& Graf.

Pakula, Hannah. 1985. The Last Romantic: A Biography of Queen Marie of Romania. Toronto: Simon and Schuster.

Peter, Jones. 2015. Track Two Diplomacy in Theory and Practice. Stanford, CA: Stanford University Press.

Queen Marie. 1926. In Memory of Joe Boyle, The Aspen Daily Times, 17 Nov 1926.

Rodney, William. 1974. Joe Boyle, King of the Klondike. Toronto: McGraw-Hill Ryerson.

Romașcanu, Mihail Gr. 2000. Tezaurul român de la Moscova. Bucharest: Editura Saeculum.

Saint-Aulaire, Contele de. 2002. Confesiunile unui bătrân diplomat. Bucharest: Humanitas.

Sauerwein, Stan. 2003. Klondike Joe Boyle: Heroic Adventures from Gold Fields to Battlefields. Canmore, AB: Altitude.

Torrey, Glenn E. (ed). 1987. General Henri Berthelot and Romania. Memoires et Correspondance 1916-1919. Boulder and New York: East European Monographs, Columbia University Press.

Torrey, Glenn E. 2011. The Romanian Battlefront in World War I. Lawrence, KS: University Press of Kansas. 